\title{
The Polygamy and the Economics Power(Study Polygamy in Surabaya, East Java, Indonesia)
}

\author{
Ibnu Elmi A.S. Pelu \\ Lecturer of Law, Faculty of ShariaState Islamic Institute (IAIN) of Palangkaraya Indonesia,
}

\begin{abstract}
The motive of polygamy in Indonesia is very diverse. Public perception against one of the motives of polygamy is very strong due to economic problems. Economic motives as power for of polygamy is not always right.This paper mainstreem denied the presumption that of polygamy carried out by economic forces. In short those who practice polygamy only potentially be implemented for the rich or the elite tier of other groups.

Theoretically-normatively basic theory which became one of the parameters can be polygamous in Indonesia, namely the existence of evidence of the husband's income would be polygamous is a figure that could provide for the economy to all the wives and children. The result is that a strong economic motive is considered the basis for of polygamy was not entirely right.In Surabaya, for example secretly polygamous husband of 64 polygamous marriages procedural was only earning less than Rp. 17 million. Of these $39 \%$ are self-employed husband by profession who earn no more than 2.5 million per month, and 31.3\% earn Rp. 4.9 million. While polygamous husband in secret of 56 polygamous marriages only income below 24 million. Of these the most that $50 \%$ are self-employed husband by profession who earn no more than 2.4 million every month.
\end{abstract}

Keywords: Polygamy, Power Economics

\section{INTRODUCTION}

One of the crucial issues related to the sexual relationship of men and women, who recorded the history of Islamic civilization is the problem of polygamy (ta'addud al-zaujat). ${ }^{1}$ Formerly among the nations that run before the arrival of Islam of polygamy are a Hebrew, Arabic, Jahiliyyah, and Cecilia. ${ }^{2}$ But until now, even though of polygamy is accepted widely by Muslims, when practiced still an issue and debate among the community.Similarly in Indonesia, polygamy is still one problem in marriage is the most talked about and controversial. In one side, polygamy was rejected with a variety of arguments, both normative, psychological, even linked to gender inequality. Even Western writers, often claim that polygamy is evidence that the teaching of Islam in the areas of marriage is very discriminatory against women. On the other hand, polygamy campaigned as having normatively firm backrest and is seen as one of the alternatives to solve the phenomenon of cheating and prostitution.

Early tug problem polygamy in Indonesia, has been to the fore when triggered by the height of the news about the success of PuspoWardoyo in polygamy. Polygamy Rooster that the PuspoWardoyo nickname's, which nothing else is but the descendants of grilled chicken trader from Solo. The PuspoWardoyosuccessis not because of barbecued chicken business success their parents, but a success because it has been a polygamist four wives. ${ }^{3}$ This situation, the behavior of the various media conversation, when the issue of polygamy, shocked by the practice of polygamy Aa Gym. This phenomenon, in turn led some communities, where the understanding of society at that time, constructs itself, that polygamy as is the order or at least a suggestion of religion. Based on those polygamists successful, proud to have succeeded in proving "command" of the religion. Pride was deeply felt by the presence Polygamy Award (A tribute to polygamists), which is annually awarded to those who are considered successful in fostering polygamy households. ${ }^{4}$

Next, after news of polygamy gradually subsided, perform a businessman brass, namely Sheikh Puji, who married polygamy. Sheikh Puji this case, not only chaos because a wife is more than one, but it has been linked LutfiyanaUlfa, underage girl whom he had married. "Let's polygamy, even small children are also

\footnotetext{
${ }^{1}$ Besides polygamy, the crucial issue is the sexual relationship because of proprietary al-Yamin (slavery) and sexual relations marriage contract. The issue of slavery is lost without any clear legal status in the form of an explicit, contract marriage issue was rejected by a majority of Sunni scholars and polygamy has been widely accepted, but with strict requirements involving. See: Faqihuddin Abdul Kodir, Choosing Monogamy; The reading of the Qur'an and the Hadith of the Prophet (Yogyakarta: PustakaPesantren, 2005), ix.

${ }^{2}$ SayyidSabiq, FiqhSunnah, Volume 3, Translation NorHasanuddin (Jakarta: Pena PundiAksara, 2007), p. 9.

3 Abdul Matin Salman, Polygamy Education: Thoughts and Attempts Enlightenment PuspoWardoyo on Polygamy (Solo: CV. BumiWacana, 2008), p. 45.

${ }^{4}$ AnshoriFahmie, Who Says Polygamy was Sunnah? (Bandung: PustakaIIMaN, 2007), p. 9. 
married to him". As a result of this case, eventually Sheikh Puji is in prison, on charges of exploiting minors. Not much later, reappeared polygamy community in Bandung, led by Global Ikhwan, which is nothing but a subsidiary of the polygamy community in Malaysia. The presence of this community, it makes people uneasy everywhere. The emergence of civil unrest, in particular that hit most of these mothers, eventually forcing MUI West Java province, issued an edicts a ban on the community.

Based on the various cases of polygamy above, certainly needed a fundamental explanation about polygamy. So people do not worry and know the problems of polygamy. One of the causes, the emergence of the practice of polygamy on the one hand, and the emergence of public unrest on the other, which is due to the lack of knowledge, for what reason or motive that became the basis of polygamy. If the reason or motive, it is known widely, especially when the reason it is set in the legislation in force, researchers believe there will be no news reports or rumors about polygamy. Similarly with the procedure of the polygamy. Community or even a polygamist himself, seem not to fully implement and know all about the procedure polygamy. The effects of the problem, would lead to the ignorance of the social implications due to polygamy.

There are some facts that prove that, based on the perception of the above; the practice of polygamy has spread in parts of Indonesia. At least 989 have been recorded polygamy permit application filed in the Court of religion throughout Indonesia. Of these, approximately $81 \%$ has been granted the petition and permitted the Religious Court, while $19 \%$ of the application is rejected. However, in other side the divorce rate which is caused by polygamy also did not lose the high level. As in 2005 , the divorce as a result of polygamy in some parts of Indonesia such as Bandung, Surabaya and Semarang. In the High Court Religion of Bandung, recorded at least 324 cases of divorce caused by polygamy. Second in the same case also happened in Surabaya with 162 divorce cases. Semarang city followed by 104 cases. ${ }^{5}$ The figures are, of course, surprising. This is due to indications that some practices polygamy, not based on reason and through standard procedures as the existing regulations. If you look at the data above, it is conceivable if through litigation practice polygamy just crawl up, then what if the practice of polygamy is done through a process of non-litigation.

To put the problem, the issue of polygamy in Indonesia has been regulated in several laws, such as Act No. 1 of 1974 on Marriage, the Indonesian Government Regulation No. 9 of 1975 on the Rules of implementation of Law No. 1 of 1974 on Marriage. For Civil Servants (PNS) contained in Government Regulation No. 10 of 1983 as amended by Government Regulation No. 45 of 1990 on Marriage and Divorce Permit for Civil Servants. As for as the substantive legal for Muslims, there are provisions in the Indonesian Presidential Instruction No. 1 of 1991 concerning of Islamic Law Compilation (KHI).

The provisions contained in Act No. 1 of 1974 on Marriage, the following are the rules of procedure and KHI, in principle, in line with the provisions of Islamic law. According to the legislation in principle the system adopted by the marriage laws in the Republic of Indonesia is the principle of monogamy, that one husband for one wife. ${ }^{6}$ The principle is based on the word of Allah SubhanahwwaTa'ala in Al-Qur'an surah anNisa verse $3:^{7}$

The Meaning: "And if you fear you will not be able to deal justly against (rights) female orphans (if ye marry), then marry women (the other) that you enjoy: two, three, or four. Then if you fear you cannot do justice, then (marry) only one, or the slaves whom you had. That is closer to not doing injustice." 8

However, in the case of certain reasons, a husband given permission for have wives more than one. Things reason or is reflected in a series of severe requirements of course. Then to Indonesia, whether or not a husband and have wives of more than one person, determined by the Religious Courts are met based on whether or not the requirements in Act No. 1 of 1974 on Marriage, Article 4 and 5 of paragraph (1) and Article 55 KHI. Not quite, applicants must also pass several trial procedures in the Religious Court by submitting a written application.

Although, according to the rules allowed, the severity of the requirements that must be taken, suggesting that the procedures for polygamy in the Religious Court, the principle of closing the door is open, meaning that the door was not opened polygamy if it is not needed, and only in certain circumstances, the door opened. Those conditions as described in article 4 of Law No. 1 of 1974, that a husband can have wives, more than one, if; the wife cannot perform its obligations as a wife; wife got a disability or illness that is not curable; and, the wife cannot give birth to offspring.

In addition to the above provisions, a husband who wants to practice polygamy must meet the requirements contained in article 5, paragraph (1) of Law No. 1 of 1974, as the consent of the wife or wives; the

\footnotetext{
${ }^{5}$ WahyuWidiana, "Reveals the Dark Side of Polygamy," inhttp://www.hukumonline.com/detil.asp?id=15941\&cl=fokus (21 February 2006).

${ }_{7}^{6}$ Abdul Manan. Various Problems Civil Law of Islam in Indonesia. (Jakarta: KencanaPrenada Media Group, 2008 ), 6.

${ }^{7}$ Ministry of Religious Affairs of the Republic of Indonesia. The Al-Qur'an and its translation (Jakarta: CV. Toha Putra Semarang, 1989), p. 115.

${ }^{8} \mathrm{Al}-$ Qur'an.4 (al-Nisa), 3. 
certainty that the husband is able to guarantee the necessities of life wives and their children; and a guarantee that her husband would be fair to his wife and their children.

The requirements of polygamy are also contained in KHI, namely Article 55 which states that:

(1) Wives more than one person at the same time, limited only up to four wives.

(2) The main requirement have wives more than one person, the husband should be able to do justice to the wives and children.

(3) If the main requirements referred to in paragraph (2) cannot be met, the husband is forbidden to have more than one person.

From the description of the articles regarding the polygamy requirements, it seems clear that in order to qualify is not easy. Viewed background Surabaya city residents are varied, both in terms of employment, ethnic, cultural and other social level, it is possible polygamists also have different reasons.

As research conducted by LBH-PIK Jakarta, stating that the reason polygamist quite diverse, in fact almost entirely disregard the rules as described above. The study focused on the Jakarta area, it has been concluded that $47 \%$ polygamy, and husbands influenced or tempted by other women, $22 \%$ polygamy based reason not to have children, economic reasons as well as a variety of other reasons that are not in accordance with the provisions of the Act applicable to a fairly high percentage. ${ }^{9}$

It is possible that in Surabaya, too. Seeing the Surabaya region with a population of nearly 3 million people, and is the second largest city in Indonesia, with a variety of social level, it is possible polygamous marriages are based on the application also varies. ${ }^{10}$

From the various those phenomena, which led the researchers wanted to find any motive polygamists, especially in Surabaya. Besides wanted to find out whether the dominant economic motive enough for polygamists in Surabaya.

\subsection{Legal Polygamy in Islam}

\section{DISCUSSION}

Talking about the law of polygamy in Islam, of course closely related to the verses of the Qur'an as in the letter al-Nisa'and some Hadith of Prophet Muhammad about polygamy. Verses and some Hadith are:

The meaning: "And if you fear you will not be able to deal justly against (rights) female orphans (if ye marry), then marry women (the other) that you enjoy: two, three, or four. Then if you fear you cannot do justice, then (marry) only one, or the slaves whom you had. That is closer to not doing injustice. "11

The verse above is one of the information / legal basis which are very famous for knowing the law of polygamy in Islam. In other words, if there is discussion of polygamy, you can bet this verse (Q.S. al-Nisa ${ }^{`}: 3$ ), the only valid for use. Naturally, because of the verse is explaining the permissibility polygamy, or marrying more than one woman at a time, with a maximum number of four wives, provided that fair. If you not worry cannot do justice, then simply with only one wife (monogamy).

However, the law "May" in a polygamous marriage still leaves some new paradigm in Islam. According to FazlurRahman, as quoted Abdul Mustaqim, that paragraph 3 letter al-Nisa', often interpreted partial, so as if polygamy permitted for granted, regardless of how the context of the fall of the verse, and what exactly the ethical idea behind the practice of polygamy. In paragraph 2 letter al-Nisa'for example is as follows: It means: "And give to the orphans (who have baligh) their wealth, do not you swap the good with the bad and you do not eat them together treasure. Indeed, these measures, is a great sin. " 12

The above verse gives a lesson, that before this verse was revealed, many pengampu orphans who misuse the wealth of orphans as well as eating them vanity. In addition, of the Qur'an also gives a better solution selection, namely that the pengampu who want to manage the property of orphans, the better to marry the orphan girls, than to restore their property because they want to enjoy the wealth, It is mentioned in the letter alNisa 'verse 127:

It means: "And they ask thee concerning women edicts. Say: "Allah gives you edicts about them, and what is recited to you in al-Qur'an (also edicts) about orphaned women whom you do not give them what they set out

\footnotetext{
${ }^{9}$ WahyuWidiana, "Reveals the Dark Side of Polygamy," in http://www.hukumonline.com/detil.asp?id =15941\&cl=fokus (21 February 2006).

${ }^{10}$ The Department of Population Surabaya, "The Population of Surabaya According to Jobs, Religion, Age, and the Surabaya based RT and RW 2008," in http://www.surabaya.go.id/dispenduk/?download =true\&cat=stats=file=7. (t.t.)

${ }^{11}$ Ministry of Religious Affairs of the Republic of Indonesia.The Al-Qur'an and its translation (Jakarta: CV. Toha Putra Semarang, 1989), 115.Al-Qur'an.4 (al-Nisa'), 3.

${ }^{12}$ Al-Qur'an.4 (al-Nisa'), 2. 
for them, but you want to marry them and about children who are still seen as weak. And (Allah orders you) so that you take care of the orphans equitably. And virtue, whatever you do, then verily, Allah is All-knowing. ${ }^{13}$

In paragraph 3 letter al-Nisa', also stated that if the manager (guardians) cannot do justice to the wealth of orphan girls (and they insist to marry), then they should marry the orphan girls are up to four, origin they can do justice between wives. But if worry cannot do justice to the wives, then they are told to marry a course of orphaned girls. Because of this, it is an act where they will not make mistakes and irregularities.

As for the paradigm of usulfiqh, polygamy laws can be explained by first digging a few spelling/keywords in paragraph 3 letter an-Nisa', such as fankihu, andal-'adlu. A Fankihu word, in the science of usulfiqh is the command word / amr, meaning "then marry". According to the majority of expert's fiqh and tafsir, that the general principle of "command word" in the Qur'an, have legal implicationsobligatoryandilzam ${ }^{14}$, unless thereqara ' $i{ }^{15}$, which requires a command word that means other than obligatory. Thus, the command said the Qur'an refers to two legal implications. First, a word that is not accompanied qara'incommand, and then it has an obligatory of legal implications. Second, the command word is accompanied by qara'in, then it has legal implications mubah or allowed. ${ }^{16}$ Becausefankihua meaningful form of the command word and command, as well as having the form of eligibility qarinah fair, then the law of polygamy in terms fankihuwords, the legal implications permissible.

Although lafazfankihuwas known to say, the law of polygamy cannot be judged only by the approach lafazfankihu meaning only. Furthermore, the search focused on lafaz al-'adlu which means fairness. In paragraph 3 letter al-Nisa', meaning there is fair in 2 (two) word is the word al-'adlu and al-qistu. In other words, said al-' adlu and said al-qistu have the same meaning that is fair. According to M. QuraishShihab, ${ }^{17}$ said al-'adlu and said al-qistu often synonymous and translated into Indonesian be fair. However, there are some scholars who distinguish the two words by saying that the word al-'adlu is applicable either to others or to themselves, but justice it may not be pleasant either party. While the word of al-qistu justly between two or more peoples, and the justice that make both of them happy. However, since the implementation of these two words that are in the lineup sentence has a different context, of course, the meaning of the word al-'adlu and said al-qistu hs different meaning.

The word al-qisthu referred, are in a sentence:

The meaning: "... and if you fear you will not be able to do justice to the (right) female orphans ...” (Q.S. al-Nisa': 3)

While the word al-'adlu referred, are in a sentence:

The meaning: “... if you are afraid to can’t do justice ...” (Q.S. al-Nisa‘: 3)

In the words of al-qistu, the context of the sentence in paragraph 3 letter chunks an-Nisa'is a concern cannot do justice in the context of wealth divide. Therefore, the fair meaning of the word al-qistu course oriented fair meaning materially; it means to do justice to the policy of quantitative figures. Meanwhile, al-'adlu words, the sentence in the third paragraph chunks letter an-Nisa' is a worry cannot do justice in the context of the divide compassion, love, caring, understanding among the wives. Therefore, the fair meaning of the word al'adlu directed at fair meaning is immaterial; it means to do justice to the policy value of compassion, love, caring, understanding the wives are qualitative. Because polygamy or marrying or having more than one wife demanding a fair requirement, which is located on a fair sentence:

Meaning: “... if you are afraid to can't do justice ...” (Q.S. an-Nisa': 3)

Thus, it can be concluded, that the purpose of paragraph 3 letter an-Nisa'is a gently prohibit polygamy, or allow polygamy on condition very tight, because to qualify fair qualitatively, it is difficult, even impossible to be fulfilled.

Moreover, in the study of fiqh proposal, any conditions in a religious and legal engagements, generally excluded from the act or pillars. Context requisite fair in polygamy, it seems a little different. Terms fair in polygamy, has a very unique, because it is indeed and harmonious marriage, as well as dowry. Dowry is a requirement, but within and adjacent to the pillars, but not in harmony. Therefore, because the condition is such that polygamy fair and equitable absence of a husband to his wives can only be proven after polygamy takes

\footnotetext{
${ }^{13} \mathrm{Al}-\mathrm{Qur}$ 'an.4 (al-Nisa'), 127.

14"Must."

15 "Proposition or arguments that accompany."

${ }^{16}$ Abdul Matin Salman, Polygamy Education: Thoughts and Attempts Enlightenment PuspoWardoyo on Polygamy (Solo: CV. BumiWacana, 2008), 106. Compare with Muhammad 'Ali al-Shabuni, in Rawa'i ' al-Bayan TafsirAyat al-Ahkam Min al-Qur'an, Chapter I (Beirut: Dar Al-Fikr, t.t.), p. 334.

${ }^{17}$ M. QuraishShihab, Tafsir al-Misbah (Messages, impressions and harmony of the Qur'an), Vol. II (Jakarta: LenteraHati, 2006), 338 . 
place, the the law of polygamy, by placing a requisite fair is an attitude that builds upon commitments spirit and high morale. According to the authors, human characters such as these, it is hard to find, especially at times like this. Therefore, the law of polygamy in this paradigm, is Sunnah but must qualify that is fair.

Still related to the fair as a condition for polygamy, that generally, the fair includes two things: fair in intercourse and fair in terms of providing necessities of life. Although fair terms are meant to be limited on things that might be done and controlled human justice qualitative fixed rate will not be able to do given the limitations as humans. It is enshrined in the Qur'an Surat an-Nisa'verse 129:

The meaning: And you will never be able to be equal [in feeling] between wives, even if you should strive to do so. So do not incline completely (to whom you love) and leave another hanging. ${ }^{18}$

As according to Mahmud Saltut, ${ }^{19}$ as quoted by Quarter Point Tutik explained, that the fair is meant is that a husband was not too inclined to one of his wives, and let others displaced. This is due to fair overall good of affordable or not, because it is impossible to fulfill by humans. He is based on the Hadith of the Prophet Muhammad:

Meaning: "He who has two wives, but he is more inclined to the one, then later on the day Qiyamat he would come by dragging one side was in a state of falling and tilting." 20

Meanwhile, according to Yusuf Qaradawi, ${ }^{21}$ just in a practical level of confidence in him, that he was able to do justice between wives in trouble eating, drinking, clothing, shelter, overnight, and living. If unsure of her ability to fulfill these rights in a fair and balanced, it is forbidden for him to marry more than one wife.

Besides having to go through as well as the terms and procedures above, which is no less important for a husband who wants to polygamy is the reason realistic. The reason this is what will be the basis of the feasibility of a husband's polygamy. In the tafsir of al-Maraghi, as quoted Tutik, explained that the reason or motive to carry out polygamy, that does not have a child who will connect offspring, (wife I) suffering from a chronic disease that does not allow it to perform tasks as wives generally, characters of male (husband) who has a strong libido, and the number of women is greater than men because of war and other social issues. ${ }^{22}$ With regard to the reasons for the emergency that allow polygamy, there are at least eight conditions. Among other things, the wife of a disease that is dangerous and difficult to cure, the wife proved barren and confirmed medically unable to give birth, the wife insane, wife of the elderly that cannot meet its obligations as a wife, the wife has a bad character, the wife ran away from home, their explosion in the number of women as war, have wives needs more than one can cause harm to the life and work if it is not fulfilled. ${ }^{23}$

\subsection{The Polygamy and the Economics Power}

In Webster's New World Dictionary, as cited by Jamilah Jones, ${ }^{24}$ the term polygamy is defined as the practice of marriage with a woman (wife) or man (husband) over a at the same time. In addition to these terms, polygamy has a synonym, that polygyny. Polygyny is the practice of marriage with two women (wife) or more at the same time. Instead, the practice of marriage with two men (husband) or more at the same time is called polyandry. The practice of marriage of a husband/wife with a husband/wife at the same time is called monogamous. have wives associated with more than one at the same time, it seems to the general public, particularly the people of Surabaya, more commonly use the term polygamy than the polygyny.

Geographically, the city of Surabaya is located between $07^{\circ} 12^{\prime}-07^{\circ} 21^{\prime}$ South Latitude and $112^{\circ} 36^{\prime}$ $112^{\circ} 54^{\prime}$ east longitude. Surabaya town located north tip of the island of Java. Surabaya city has an area of $326.36 \mathrm{~km}$, with a population at the 2002 census numbered 2.484 .583 people. If the number of the population compared with the existing area, the population density of the city of Surabaya on average 7.613 people/Km. whereas in 2009, the population of the city of Surabaya has reached nearly 3 million inhabitants. The total area of Surabaya is divided into five major regions, with 31 districts consisting of 163 villages. For North Surabaya region consists than seven districts. South Surabaya region consists than seven districts. Surabaya East region consists than seven districts. West Surabaya area consists than 6 districts. While the area of Surabaya center consists than 4 districts. The following table division administrative area of Surabaya city:

\footnotetext{
${ }^{18} \mathrm{Al}$-Qur'an.4 (an-Nisa'), 129.

${ }^{19}$ TitikTriwulanTutik, Polygamy Perspective of Marriage Engagements; Contextual study According to Islamic Law and the Marriage Law No. 1 of 1974 (Jakarta: PrestasiPustaka, 2007), p. 71.

${ }^{20}$ Abu Dawud, Sulaymanibn al-Ash'ath al-Sijistaniy. SunanAbiDawud (Cairo: Dar al-Fikr, t.t.), 133.

${ }^{21}$ Yusuf Qardhawi, Halal and Haram in Islam, Translation Abu Sa 'id Al-Falahi(Jakarta: Robbani Press, 2000), p. 214.

${ }^{22}$ Tutik, Polygamy Perspective..., p. 73.

${ }^{23}$ AmiurNuruddin, Civil Law of Islam in Indonesia; Critical Study Development of Islamic Law of Jurisprudence, Law No. 1 of 1974 to KHI (Jakarta: KencanaPrenada Media Group, 2006), p.159.

${ }^{24}$ Jamilah Jones and Abu Aminah Bilal Philips, Plural Marriage in Islam, Translation MachnunHusein (Jakarta: PT. RajaGrafindoPersada, 2001), p. 1. 
Table. 1 Table of Regional Distribution of SurabayaCity Governments Administration. ${ }^{25}$

\begin{tabular}{|c|c|c|c|}
\hline No. & $\begin{array}{l}\text { REGIONA } \\
\text { L }\end{array}$ & SUB-DISTRICT & VILLAGE \\
\hline \multirow[t]{7}{*}{1.} & \multirow{7}{*}{$\begin{array}{l}\text { North } \\
\text { Surabaya }\end{array}$} & Semampir & Ampel, Sidotopo, Pegirian, Wonokusumo, Ujung \\
\hline & & Krembangan & $\begin{array}{l}\text { Dupak, Moro Krembangan, Perak Barat, Kemayoran, } \\
\text { Krembangan Selatan }\end{array}$ \\
\hline & & Kenjeran & $\begin{array}{l}\text { Tanah Kali Kedinding, SidotopoWetan, BulakBanteng, } \\
\text { TambakWedi }\end{array}$ \\
\hline & & AsemRowo & AsemRowo, Genteng, KalianakGreges \\
\hline & & PabeanCantikan & $\begin{array}{l}\text { Bongkaran, Nyamplungan, Krembangan Utara, Perak } \\
\text { Timur, Perak Utara }\end{array}$ \\
\hline & & SukoManung. & $\begin{array}{l}\text { Tanjung Sari, SukoManunggal, } \\
\text { SonoKwijenan,PutatGede }\end{array}$ \\
\hline & & Bulak & Sukolilo, Kenjeran, Bulak, KedungCowek, Komp. Kenjeran \\
\hline \multirow[t]{7}{*}{2.} & \multirow[t]{7}{*}{$\begin{array}{l}\text { South } \\
\text { Surabaya }\end{array}$} & Wonokromo & $\begin{array}{l}\text { Wonokromo, Sawunggaling, Darmo, Ngagel, } \\
\text { NgagelRejo, Jagir }\end{array}$ \\
\hline & & Wonocolo & $\begin{array}{lccc}\text { Sidosermo, } & \text { BendulMerisi, } & \text { Margo } & \text { Rejo, } \\
\text { JemurWonosari,SiwalanKerto }\end{array}$ \\
\hline & & Gayungan & Gayungan, Ketintang, Menanggal, DukuhMenanggal \\
\hline & & Wiyung & Wiyung, Jajar Tunggal, Babatan, BalasKlumprik \\
\hline & & Sawahan & $\begin{array}{l}\text { Sawahan, Petemon, KupangKrajan, Banyu Urip, } \\
\text { Putat Jaya, Pakis }\end{array}$ \\
\hline & & Jambangan & Karah, Jambangan, Kebon Sari, Pagesangan \\
\hline & & KarangPilang & Kedurus, Kebraon, KarangPilang, WaruGunung \\
\hline \multirow[t]{7}{*}{3} & \multirow[t]{7}{*}{$\begin{array}{l}\text { East } \\
\text { Surabaya }\end{array}$} & Gubeng & $\begin{array}{l}\text { Gubeng, Airlangga, Mojo, Kertajaya, PucangSewu, } \\
\text { Barata Jaya }\end{array}$ \\
\hline & & Rungkut & $\begin{array}{l}\text { RungkutKidul, Kali Rungkut, KedungBaruk, } \\
\text { Penjaringan Sari, MedokanAyu, WonoRejo }\end{array}$ \\
\hline & & Tambak Sari & $\begin{array}{l}\text { Tambak Sari, PacarKeling, PacarKembang, Ploso, } \\
\text { Rangkah, Gading }\end{array}$ \\
\hline & & MulyoRejo & $\begin{array}{l}\text { Mulyorejo, Kalijudan, } \quad \text { ManyarSabrangan, } \\
\text { DukuhSutorejo, Kali Sari, KejawanPutihTambak }\end{array}$ \\
\hline & & Sukolilo & $\begin{array}{l}\text { MenurPumpungan, } \\
\text { KlampisNgasem, Semolowaru, MedokanSemampir, } \\
\text { GebangPutih, Keputih }\end{array}$ \\
\hline & & GunungAnyar & $\begin{array}{l}\text { GunungAnyar, GunungAnyarTambak, RungkutMenanggal, } \\
\text { Rungkut Tengah }\end{array}$ \\
\hline & & TenggilisMejoyo & $\begin{array}{l}\text { TenggilisMejoyo, PanjangJiwo, Prapen, Kendang } \\
\text { Sari, Kutisari }\end{array}$ \\
\hline \multirow[t]{6}{*}{4.} & \multirow[t]{6}{*}{$\begin{array}{l}\text { West } \\
\text { Surabaya }\end{array}$} & Tandes & $\begin{array}{l}\text { Buntaran, BanjarSugihan, ManukanKulon, ManukanWetan, } \\
\text { Bibis, Balong Sari, KarangPoh, Gadel, Tubanan, TandesLor, } \\
\text { TandesKidul, GedangAsin }\end{array}$ \\
\hline & & Benowo & $\begin{array}{l}\text { Kandangan, KlakahRejo, Sememi, , Romokalisari, } \\
\text { TambakOsowilang. }\end{array}$ \\
\hline & & Dukuh Pakis & Dukuh Pakis, DukuhKupang, Gunung Sari, Prada Kalikendal \\
\hline & & Pakal & $\begin{array}{l}\text { Pakal, BabatJerawat, TambakDono, SumberRejo, } \\
\text { Benowo }\end{array}$ \\
\hline & & SambiKerep & Bringin, Made, SambiKerep, Lontar \\
\hline & & LakarSantri & $\begin{array}{l}\text { Jeruk, LakarSantri, LidahKulon, LidahWetan, } \\
\text { Bangkingan, SumurWelut }\end{array}$ \\
\hline \multirow[t]{5}{*}{5.} & \multirow{4}{*}{$\begin{array}{l}\text { Surabaya } \\
\text { Center }\end{array}$} & Tegal Sari & Keputran, Dr. Sutomo, Tegal Sari, Wonorejo, Kedung Doro \\
\hline & & Simokerto & Kapasan, TambakRejo, Simokerto, Sidodadi \\
\hline & & Bubutan & Bubutan, Alun-alunContong, TembokDukuh, Gundih, Jepara \\
\hline & & Genteng & EmbongKaliasin, Ketabang, Genteng, Peneleh, Kapasari \\
\hline & 5 Region & 31 Sub Districts & 163 Villages \\
\hline
\end{tabular}

${ }^{25}$ Surabaya Map.The Development and Distribution Administration (PT. Karya Pembina Swajaya). t.t. 
Regarding the construction of social, cultural, and economicalthe population of Surabaya city very diverse. In the aspect of social-cultural, Surabaya's population is composed than multi-ethnic, such as Javanese, Sundanese, Batak, Dayak, Bali, Melayu and Bugis. However, the majority ethnic groups living in the city is dominated by ethnic Suroboyoan and Madura. In addition to occupy by several ethnic archipelagos, Surabaya is also loved by ethnic foreign countries, such as China, India, Arab and Spanish.

From an economic perspective, Surabaya is the center of industry is vital in producing, receiving and distributing a variety of products, both in the form of goods, such as materials of basic needs, secondary, tertiary or services. The main objective than this economic circulation, the other does not make the Surabaya city as a center of trade, and facilitate the various demands for the eastern part of Indonesia, such as Kalimantan, Sulawesi, Bali, Maluku, NTB, NTT and Irian Jaya. As an economic center, it is normal that the population of Surabaya did have professional backgrounds vary, and fully furnished. Starting from the Household helpers to officials, ranging from scavenger to businessmen, even a profession of "bondonekat"until Muslim preachers $\left(d a^{\prime} i\right)$ available in full in Surabaya. Not only that, lucrative profession, began selling homemade products, to sell themselves can also be enjoyed and found easily on earth of a city that has a hero icon.

Related to the marriage (polygamy), most residents of the city of Surabaya also practice such marriage. Investigations by investigators, was a polygamist in Surabaya have a foundation and motives vary in polygamy.

So far, not only polygamy motives are diverse, but the economic background, education, profession and age actors (especially the husband), has a separate phenomenon in terms of polygamy in Surabaya. Of the 64 applications for permission to be granted polygamy Religious Court judges Surabaya, from 2005 to 2008 , and 56 cases of secret polygamy, who successfully investigated, researchers categorizing some models of the practice of polygamy, based on social and economic construction of Surabaya.

If visits by type of profession and polygamous husband's income, can be seen in the following table:

Table 2.The Distribution of procedural polygamy based on profession / husband's occupation. ${ }^{26}$

\begin{tabular}{|c|c|c|c|c|c|c|c|}
\hline \multirow{2}{*}{$\begin{array}{l}\mathbf{N} \\
\text { o. }\end{array}$} & \multirow[t]{2}{*}{ Profession Type / Occupation } & \multicolumn{4}{|c|}{ Year } & \multirow[t]{2}{*}{ Amount } & \multirow[t]{2}{*}{$\%$} \\
\hline & & $\begin{array}{c}200 \\
5\end{array}$ & 2006 & 2007 & 2008 & & \\
\hline 1 & $\begin{array}{l}\text { Civil Servants / The Military / } \\
\text { Police }\end{array}$ & 1 & - & - & - & 1 & 1,6 \\
\hline 2 & Lawyer & - & - & - & 1 & 1 & 1,6 \\
\hline 3 & Trader & 1 & 2 & - & - & 3 & 4,6 \\
\hline 4 & Security & 1 & 1 & 1 & - & 3 & 4,6 \\
\hline 5 & Driver & - & 1 & - & - & 1 & 1,6 \\
\hline 6 & Parking Attendants & - & 1 & - & - & 1 & 1,6 \\
\hline 7 & Private & 8 & 9 & 18 & 18 & 53 & 82,8 \\
\hline 8 & Collectors & - & 1 & - & - & 1 & 1,6 \\
\hline & Total & 11 & 15 & 19 & 19 & 64 & 100 \\
\hline
\end{tabular}

According to the table above, in the case of polygamy appropriate permit procedure through Religious Court, that the types of professions the most widely implement polygamy is a husband who works as a selfemployed. The amount those were up to $82 \%$ or as much as 53 husbands. While most other professions is a trader and a security guard husband as much as 3 or $4.6 \%$ followed by professional PNS, Advocate, driver, Plumbers parking, and collectors.

Table 3.The Distribution of procedural polygamy based on husband's income ${ }^{27}$

\begin{tabular}{|c|c|c|c|c|c|c|c|}
\hline $\mathbf{N}$ & \multirow[t]{2}{*}{ Income Total } & \multicolumn{4}{|c|}{ Year } & \multirow[t]{2}{*}{ Amount } & \multirow[t]{2}{*}{$\%$} \\
\hline o. & & 2005 & 2006 & 2007 & 2008 & & \\
\hline 1 & Follow Parent/ Wife & - & - & - & - & - & - \\
\hline 2 & $<1$ million & 2 & 2 & - & 1 & 5 & 7,8 \\
\hline 3 & 1 million $-2,4$ million & 3 & 6 & 8 & 8 & 25 & 39,1 \\
\hline 4 & 2,5 million $-4,9$ million & 4 & 7 & 3 & 6 & 20 & $\mathbf{3 1 , 3}$ \\
\hline 5 & 5 million $-7,4$ million & 1 & - & 4 & 2 & 7 & $\mathbf{1 0 , 9}$ \\
\hline
\end{tabular}

\footnotetext{
${ }^{26}$ Archives, observations, Surabaya Religious Court, dated July 28, 2009.

27 Archives, observations, Surabaya Religious Court, dated July 28, 2009
} 


\begin{tabular}{|l|l|c|c|c|c|c|c|}
\hline 6 & 7,5 million $-9,9$ million & 1 & - & 1 & - & $\mathbf{2}$ & $\mathbf{3 , 1}$ \\
\hline 7 & 10 million $-12,4$ million & - & - & 1 & 2 & $\mathbf{3}$ & $\mathbf{4 , 6}$ \\
\hline 8 & 12,5 million $-14,9$ million & - & - & - & - & - & - \\
\hline 9 & 15 million $-17,4$ million & - & - & 2 & - & $\mathbf{2}$ & $\mathbf{3 , 1}$ \\
\hline 10 & $>17,5$ million & - & - & - & - & - & - \\
\hline \multicolumn{2}{c}{ Total } & $\mathbf{1 1}$ & $\mathbf{1 5}$ & $\mathbf{1 9}$ & $\mathbf{1 9}$ & $\mathbf{6 4}$ & $\mathbf{1 0 0}$ \\
\hline
\end{tabular}

As based on the husband's income, in the case of polygamy appropriate permit procedure through Religious Court, that the incomelevels of the most widely implement polygamy is a husband who earn between 2.4 million to 4.9 million. The amount that reached $39.1 \%$ and $31.3 \%$. While other income is income from 5 to 7.4 million, and those who earn up to 17.4 million.

Table 4.The distribution of secrecy polygamy based on professional / husbands occupation. ${ }^{28}$

\begin{tabular}{|l|l|c|c|c|}
\hline $\begin{array}{l}\mathbf{N} \\
\text { o. }\end{array}$ & Profession Type / Occupation & Data Collection Year 2009 & Amount & \% \\
\hline 1 & $\begin{array}{l}\text { Civil servants / the military / } \\
\text { Police }\end{array}$ & $7 / 1 / 1$ & $\mathbf{9}$ & $\mathbf{1 6 , 1}$ \\
\hline 2 & Businessman & 7 & $\mathbf{7}$ & $\mathbf{1 2 , 5}$ \\
\hline 3 & Realtor land & 1 & $\mathbf{1}$ & $\mathbf{1 , 8}$ \\
\hline 4 & Farmer & 3 & $\mathbf{3}$ & $\mathbf{5 , 4}$ \\
\hline 5 & Trader & 1 & $\mathbf{1}$ & $\mathbf{1 , 8}$ \\
\hline 6 & Driver & 3 & $\mathbf{3}$ & $\mathbf{5 , 4}$ \\
\hline 7 & Parking attendants & 1 & $\mathbf{1}$ & $\mathbf{1 , 8}$ \\
\hline 8 & Private & 23 & $\mathbf{2 3}$ & $\mathbf{4 1 , 1}$ \\
\hline 9 & Employee & 3 & $\mathbf{4}$ & $\mathbf{5 , 4}$ \\
\hline 10 & Pedicab driver & 1 & $\mathbf{1}$ & $\mathbf{1 , 8}$ \\
\hline 11 & $\begin{array}{l}\text { Incantation workman } \\
\text { (Peruqyah) }\end{array}$ & $\mathbf{5 6}$ & $\mathbf{5 6}$ & $\mathbf{1 0 0}$ \\
\hline
\end{tabular}

Whereas in the case of secretly polygamy, that profession most widely implement polygamy is a husband who works as a self-employed. The numbers reaching $41.1 \%$ or as many as 23 husbands of 56 husbands. While most other professions are PNS/military/police as much as $16.1 \%$, then employers $12.5 \%$, followed by pedicab driver much as $7.2 \%$, then the farmers, employees, and Incantation (rukyah) and realtor.

Table 5.The distribution of secrecy polygamy based on husband's income. ${ }^{29}$

\begin{tabular}{|l|l|c|c|c|}
\hline $\begin{array}{l}\text { N } \\
\text { o. }\end{array}$ & \multicolumn{1}{|c|}{ Income total } & Data Collection Year 2009 & Amount & \% \\
\hline 1 & Follow Parent/ Wife & - & - & - \\
\hline 2 & $<1$ million & 5 & $\mathbf{5}$ & $\mathbf{8 , 9}$ \\
\hline 3 & 1 million $-2,4$ million & 28 & $\mathbf{2 8}$ & $\mathbf{5 0}$ \\
\hline 4 & 2,5 million $-4,9$ million & 9 & $\mathbf{9}$ & $\mathbf{1 6 , 1}$ \\
\hline 5 & 5 million $-7,4$ million & 5 & $\mathbf{5}$ & $\mathbf{8 , 9}$ \\
\hline 6 & 7,5 million $-9,9$ million & 3 & $\mathbf{3}$ & $\mathbf{5 , 4}$ \\
\hline 7 & 10 million $-12,4$ million & 3 & $\mathbf{3}$ & $\mathbf{5 , 4}$ \\
\hline 8 & 12,5 million $-14,9$ million & - & - & - \\
\hline 9 & 15 million $-17,4$ million & 1 & $\mathbf{1}$ & $\mathbf{1 , 8}$ \\
\hline 10 & 17,5 million $-19,9$ million & - & - & - \\
\hline 11 & 20 million $-22,4$ million & 1 & $\mathbf{1}$ & $\mathbf{1 , 8}$ \\
\hline 12 & 22,5 million $-24,9$ million & 1 & $\mathbf{1}$ & $\mathbf{1 , 8}$ \\
\hline 13 & 25 million $-27,4$ million & - & - & - \\
\hline 14 & 27,5 million $-29,9$ million & - & - & - \\
\hline
\end{tabular}

\footnotetext{
${ }^{28}$ Interview results, Surabaya. Date August 1 to January 30, 2010.

${ }^{29}$ Interview results, Surabaya, Date August 1 to January 30, 2010.
} 


\begin{tabular}{|c|c|c|c|c|}
\hline 15 & $>30$ million & - & - & - \\
\hline \multicolumn{1}{|c|}{ Total } & $\mathbf{5 6}$ & $\mathbf{5 6}$ & $\mathbf{1 0 0}$ \\
\hline
\end{tabular}

As based on the husband's income, in the case of secretly polygamy, that the income level of the most widely implements polygamy is a husband earning 1 to 2.4 million as many as 28 or $50 \%$. While another income was earn that is counted from 5 to 7.4 million are amounted 9 husbands or $16.1 \%$. Then followed the income earned by 7 million by 5 husbands, husbands earn the next 37.5 million to 12.4 million, and a husband with an income of no more than 25 million in just one person. The above list is certainly interesting if it is associated with polygamy through the power of economic reasons.Based on the above data, it turns out polygamy in Surabaya when viewed from an economic standpoint; it has unique character polygamy from an economic standpoint. The character indicates that the economic power as a base polygamy was not always dominant. This means that as long as the notion that polygamy is justified always associated only is done if her husband was not entirely appropriate rich. Therefore, al-'adlu in paragraph polygamy is not only meant as ability in quantitative economic responsibility but the responsibility of the divine form of compassion, as the love of God is infinite justice that cannot be measured quantitatively.

\section{CONCLUSION}

The motive polygamy in Indonesia is very diverse. Public perception one very powerful motive polygamy is due to economic problems. The motive power for the economy as polygamy was not always right. This paper denied the mainstream presumption that polygamy carried out by economic forces. In short those who practice polygamy only potentially be implemented for the rich or the elite tier of other groups.

Theoretically-normatively, the basic theory that became one of the parameters can be polygamous in Indonesia, namely the existence of evidence of the husband's income would be polygamous is a figure that could provide for the economy to all the wives and children. The result is that a strong economic motive is considered the basis for polygamy was not entirely right.

In Surabaya, for example, the husband that polygamous by secretly of procedural polygamous marriages was only earning less than Rp. 17 million. Of these amount 39\% are self-employed husband by profession who earn no more than 2.5 million per month, and $31.3 \%$ earn Rp. 4.9 million. While polygamous husband of 56 polygamous secret marriages was only earning less than 24 million. Of these the most that $50 \%$ are selfemployed husband by profession who earn no more than 2.4 million every month.

\section{REFERENCES}

[1] Faqihuddin Abdul Kodir, Choosing Monogamy; Reading of the Qur'an and the Hadith of the Prophet (Yogyakarta: PustakaPesantren, 2005).

[2] SayyidSabiq, FikihSunnah, Jilid 3, Terj. Nor Hasanuddin (Jakarta: Pena PundiAksara, 2007).

[3] Abdul Matin Salman, Polygamy Education: Thoughts and Attempts Enlightenment PuspoWardoyo on Polygamy (Solo: CV. BumiWacana, 2008).

[4] AnshoriFahmie, Who Says Polygamy was Sunnah? (Bandung: PustakaIIMaN, 2007).

[5] WahyuWidiana, "Reveals the Dark Side of Polygamy,"

[6] inhttp://www.hukumonline.com/detil.asp?id=15941\&cl=fokus(21 February 2006)

[7] Abdul Manan. Various Problems Civil Law of Islam in Indonesia (Jakarta: KencanaPrenada Media Group, 2008).

[8] Ministry ofReligious Affairs of the Republic of Indonesia. The Al-Qur'an and its translation.(Jakarta: CV. Toha Putra Semarang, 1989).

[9] The Department of Population Surabaya, "The Population of Surabaya According to Jobs, Religion, Age, and the Surabaya based RT and RW 2008,"inhttp://www.surabaya.go.id/dispenduk/?download $=$ true $\&$ cat $=$ stats $=$ file $=7$. (t.t.)

[10] M. AgusSalim, "Married tendency Polygamy with Secret Married in Bangkalan, "(Thesis, IAIN SunanAmpel Surabaya, 2004).

[11] Abdul Mustaqim, "The concept of Polygamy According to Muhammad Shahrur"Journal of Sciences study of the Qur'an and the Hadith, Vol. 8, No. 1 (January, 2007).

[12] Muhammad 'Ali al-Sabuni, in“Rawa'i' al-Bayan TafsirAyat al-Ahkam Min al-Qur'an”, chapters I (Beirut: Dar Al-Fikr, t.t.).

[13] M. QuraishShihab, Tafsir al-Misbah (Messages, impressions and harmony of the Qur'an), Vol. II (Jakarta: LenteraHati, 2006). 
[14] TitikTriwulanTutik, Polygamy Perspective of Marriage Engagements; Contextual study According to Islamic Law and the Marriage Law No. 1 of 1974 (Jakarta: PrestasiPustaka, 2007).

[15] Abu Dawud, Sulaymanibn al-Ash'ath al-Sijistaniy. SunanAbiDawud (Cairo: Dar al-Fikr, t.t.).

[16] Yusuf Qardhawi, Halal and Haram in Islam, Translation Abu Sa'id Al-Falahi (Jakarta: Robbani Press, 2000).

[17] AmiurNuruddin, Civil Law of Islam in Indonesia; Critical Study Development of Islamic Law of Jurisprudence, Law No. 1 of 1974 to KHI (Jakarta: KencanaPrenada Media Group, 2006).

[18] Jamilah Jones and Abu Aminah Bilal Philips, Plural Marriage in Islam, Translation MachnunHusein (Jakarta: PT.RajaGrafindoPersada, 2001). 